Japanese P'sy hological Research

1982, Vol, 24, No. 2, 78-8

\title{
Analysis of genetic and maternal effects on behavioral development in inbred mice
}

\author{
NORIKO KODAMA \\ Department of Psychology, Faculty of Education, Shiga University, Shiga 520
}

This study was designed to investigate the strain difference of behavioral development in inbred mice, the mode of its inheritance, and the pre- and postnatal maternal effects on it. Strain difierences among five inbred strains were found in several reflexes and body movements of the young. This suggests that the difference of genetic architecture among inbred strains has significant role for the behavioral differences. Three types of the mode of inheritance in the behavioral components of the young, i.e. complete dominance, partial dominance and overdominance, were evaluated by comparing parental strains with their reciprocal hybrids. Cross-fostering between two inbred strains revealed the presence of postnatal maternal effect on the appearance of hyperreactivity and freezing, and the disappearance of hyperreactivity and crossed extensor reflex. Prenatal and postnatal maternal effects were found in the appearance of freezing and the disappearance of front placing reaction and freezing by crossfostering between reciprocal hybrids. These results show that both genetic architecture and maternal environment, pre- and postnatal, are important factors in behavioral development.

Key words: genetic effect, maternal effect, behavioral development, inbred mice, reciprocal hybrids, cross-fostering.

It is very important for developmental psychology to analyze the relative contribution of heredity and environment to the development of the young. Recently, various behavior genetic approaches have been applied to the study of development of the young, especially in the mouse, since mice have many inbred strains, which are quite useful in terms of genetic control. Several investigators compaired the behavioral clevelopment among inbred strains and heterogeneous stocks (Scudder, Karczmar, \& Lockett, 1967; McClearn, Wilson, \& Meredith, 1970; Wahlsten, 1975). In their studies, the presence of strain difference and hybrid vigor in heterogeneous stocks were found. It suggests that the genetic architecture is an important factor of the behavioral development.

${ }^{1}$ I wish to express my heart-felt thanks to Dr. Osamu Fujita and Dr. Shigehisa Sekiguchi for many valuable suggestions. My deep appreciation is also extended to Dr. Tsune Shirai for her critical reading of this manuscript.
Another factor of the behavioral development of the young is the environment, particularly the maternal environment. Several workers found that the maternal environment in prenatal and/or postnatal period modify the development of the young (Barnett \& Burn, 1967; Slob, Snow, \& de Natris-Mathot, 1973; Wainwright, 1980). Broadhurst (1961) has discussed the maternal effect on offspring behavior by cross-fostering, which is useful to detect and analyze the effect. However, few investigations have separated the prenatal from the postnatal maternal effects. Therefore, it might be possible to investigate the above factor by crossfostering between reciprocal hybrids, since their genetic architectures are the same.

The purpose of the present study is to investigate the strain difference of the behavioral development, the mode of its inheritance and the effect of the maternal environment on it. Experiment I was administered to examine the behavioral development in five inbred strains of 
mice and Experiment $I^{2}$ the postnatal maternal effect by cross-fostering between two inbred strains. The reciprocal cross was applied to Experiment $11^{3}$ to investigate the mode of inheritance and the maternal effect on reciprocal hybrids. In Experiment IV', the maternal effect on reciprocal hybrids before and after birth was cxamined by cross-fostering.

\section{Experiment I}

The purpose of this experiment was to examine the differences among five inbred strains of mice in behavioral development.

\section{Method}

Five inbred strains were used in this experiment, C57BL $6(N=41,7$ litters $)$, $\mathrm{C} 3 \mathrm{H} / \mathrm{He}(V=45,7$ litters $), \mathrm{DBA} / 2(\mathcal{N}=$ $28,6$ litters $), B+A L B / c \quad(N=32,5$ litters $)$, and $120 / S(N=51,7$ litters $)$. The strain of 120 is an inbred strain which originated from Jcl: ICR. The litter size was maintained from three to eight; those exceeding eight pups in a litter were culled at birth ( 0 day of age), and those litters of less than three pups were not adopted. Pups born at 19 days after conception were employed in this experiment. They were separated from their mothers and placed singly in the center of the observation table $(30 \times 30 \times 20 \mathrm{~cm})$ everyday during the experiment. They were subjected to one-minute observation of three behavioral components and the test of six behavioral components, which were based on Fox (1965), McClearn et al. (1970) and van Abeelen (1963).

\section{One-Minute Observation}

Pivoting. Circular locomotion caused by the side motion of the front legs with

2 A part of this study was read at the 35 th annual meeting of the Japanese Society for Animal Psychology.

3 A part of this study was read at the 40th annual meeting of the Japanese Psychological Association. the hind legs essentially inactive.

Straight walking. Locomotion in an approximately straight line with four legs in adult fashion.

Freezing. Keeping motionless with the four legs fixed more than five seconds.

\section{Tests}

Crossed extensor reflex. The flexion of a hind limb, accompanied with the extention of the opposite hind limb, when pinched.

Front placing reaction. Raising and placing a foot when the dorsum of the foot is placed in contact on the edge of the table top. The animal is suspended by the loose skin at the back of the neck.

Righting reflex (Back righting). Turning to rest in the normal position on the four legs within 20 seconds after being placed on the back by the experimenter. Rooting reflex. Pushing foward after bilateral stimulation of the face region within 20 seconds.

Hyperreactivity. Overreaction or exaggerated responsiveness to skin stimulation.

Auditory startle response. Immediate startle response such as flight or freezing reaction following a hand clap of the experimenter.

The appearance and disappearance of these behavioral components were observed and tested everyday at 0 to 34 days of age. The disappearance was determined when there was no response for two consecutive days. The temperature was kept at $28^{\circ}$ to $30^{\circ} \mathrm{C}$ when pups were observed and tested.

Body weight was measured to 1/4 of a gram after the tests everyday. The age of eyc opening was also recorded. The mother was eliminated from the home cage when the pups were at 20 days of age.

Results

The distribution patterns of days of the age when a given behavioral component 
appeared or disappeared were shown in Fig. 1. Crossed extensor and rooting reflexes already appeared at birth and disappeared almost by the age of 15 days. Pivoting appeared within five days after birth and disappeared by 20 days. Front placing reaction also appeared early and disappeared even carlier than pivoting in all strains. Back righting reflex which appeared within 10 days and walking which appeared within 15 days continued until pups were 34 days of age. Other behavioral components appeared in various days after birth and disap-
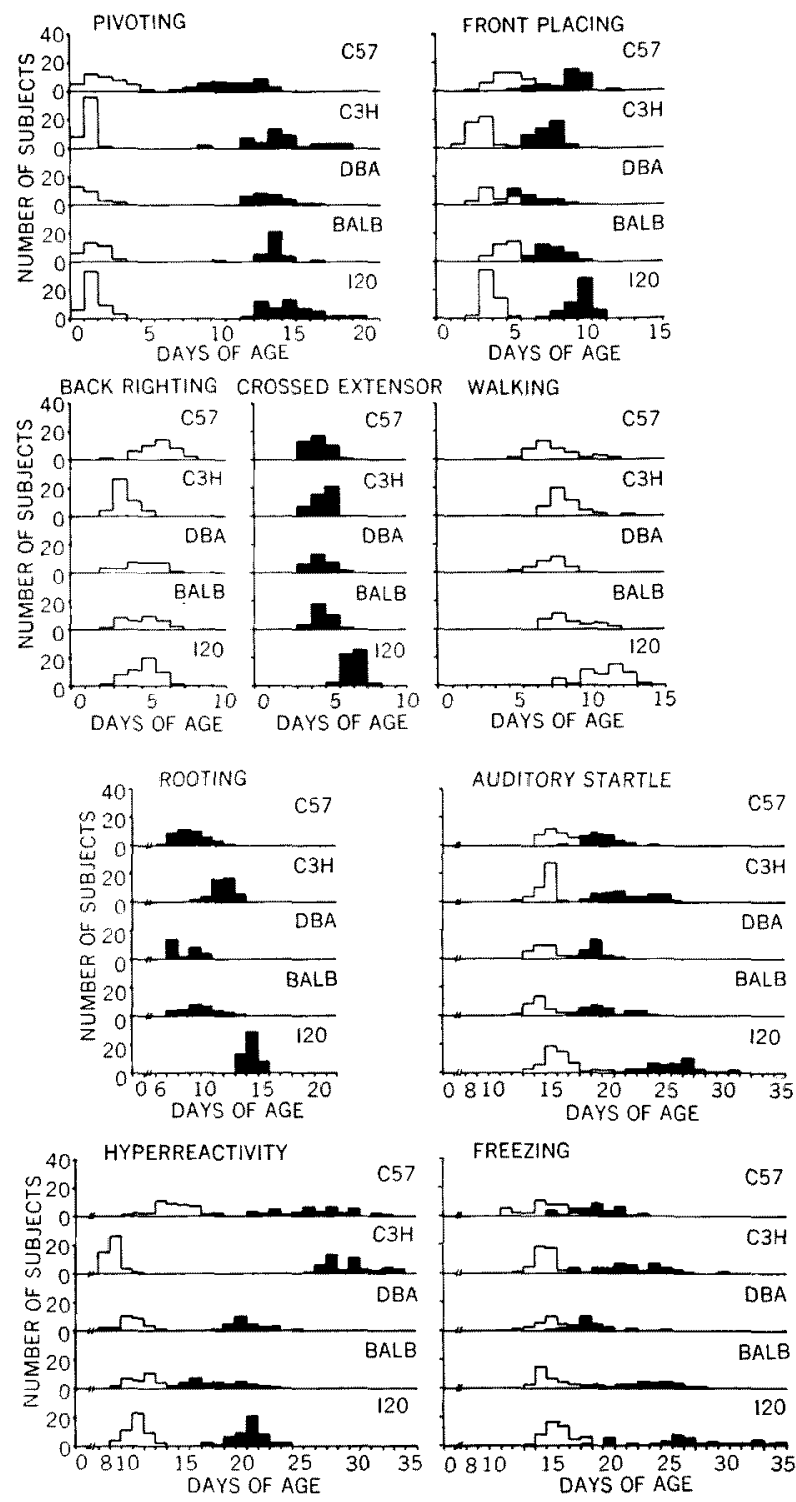

Fig. 1. Distribution patterns of behavioral components in five inbred strains. Open bars show the appearance of components and solid bars the disappearance. 
Table 1

Summary of results of Mann-Whitney $U$ test for behavioral components in five inbred strains of mice

\begin{tabular}{|c|c|c|c|c|c|c|c|c|c|c|}
\hline & $\begin{array}{c}\text { C.57 } \\
\text { vs. } \\
\text { C3H }\end{array}$ & $\begin{array}{l}\text { C57 } \\
\text { vs. } \\
\text { DBA }\end{array}$ & $\begin{array}{c}\text { C57 } \\
\text { vs. } \\
\text { BALB }\end{array}$ & $\begin{array}{l}\text { C57 } \\
\text { vs. } \\
120\end{array}$ & $\begin{array}{c}\mathrm{C} 3 \mathrm{H} \\
\text { vs. } \\
\mathrm{DBA}\end{array}$ & $\begin{array}{c}\text { C3H } \\
\text { vs. } \\
\text { BALB }\end{array}$ & $\begin{array}{c}\mathrm{C} 3 \mathrm{H} \\
\text { vs. } \\
120\end{array}$ & $\begin{array}{c}\text { DBA } \\
\text { Vs. } \\
\text { BALB }\end{array}$ & $\begin{array}{c}\text { DBA } \\
\text { vs. } \\
\text { I } 20\end{array}$ & $\begin{array}{l}\text { BALB } \\
\text { vs. } \\
\text { I } 20\end{array}$ \\
\hline \multicolumn{11}{|l|}{ Appearance } \\
\hline Pivoting & $* *$ & $* *$ & - & $* *$ & - & $* *$ & $\circ$ & $\circ$ & * & - \\
\hline Front placing & $* *$ & * & - & $* *$ & $* *$ & $* *$ & ** & * & - & $* *$ \\
\hline Back righting & $* *$ & $* *$ & $* *$ & $* *$ & $* *$ & $* *$ & ** & - & - & - \\
\hline Walking & $* *$ & - & * & $* *$ & $* *$ & - & $* *$ & $* *$ & ** & ** \\
\hline Auditory startle & $* *$ & - & * & * & - & $*$ & $* *$ & - & $* *$ & $* *$ \\
\hline Hyperreactivity & $* *$ & $* *$ & ** & $* *$ & $* *$ & $* *$ & *** & $*$ & * & 。 \\
\hline Freezing & - & - & - & ** & * & - & $* *$ & - & * & ** \\
\hline \multicolumn{11}{|l|}{ Disappearance } \\
\hline Pivoting & $* *$ & $* *$ & $* *$ & ** & - & - & - & - & $* *$ & $*$ \\
\hline Front placing & $* *$ & $* *$ & $* *$ & $* *$ & *** & - & $* *$ & ** & $* *$ & $* *$ \\
\hline Crossed extensor & $\circ$ & - & - & $* *$ & - & - & $* *$ & - & ** & ** \\
\hline Rooting & $* *$ & - & $* *$ & $* *$ & $* *$ & $* *$ & $* *$ & * & $* *$ & *** \\
\hline Auditory startle & - & - & ** & $* *$ & $* *$ & ** & $* *$ & $\circ$ & $* *$ & $* *$ \\
\hline Hyperreactivity & ** & $* *$ & $* *$ & - & $* *$ & $* *$ & $* *$ & $* *$ & - & $* *$ \\
\hline Freezing & $* *$ & - & $* *$ & $* *$ & $* *$ & - & $* *$ & $* *$ & $* *$ & $* *$ \\
\hline
\end{tabular}

peared by the age of 34 days.

The development of behavioral components examined was divided into following stages.

0-5 days of age-All pups showed crossed extensor and rooting reflex at birth. Pivoting appeared within five days in all strains, and front placing reaction and back righting reflex appeared in most pups of all strains. Crossed extensor reflex already disappeared in most strains.

6-10 days of age-Most pups were able to walk. Hyperreactivity appeared in some strains. Front placing reaction disappeared in some strains and rooting reflex began to disappear in some strains.

11-15 days of age-Freezing and auditory startle response appeared in almost half pups of all strains. Pivoting disappeared in most pups of all strains.

16-34 days of age-Hyperreactivity, auditory startle response and freezing dis- appeared with great individual and strain differences.

Summarizing the characteristics of behavioral development in each strain is as follows. In C57 strain the appearance of walking and freezing was comparatively earlier and that of hyperreactivity, front placing and back righting was delayed than the other strains. The disappearance of pivoting and freezing was earlier, whereas it was conspicuously delayed in hyperreactivity. In $\mathrm{C} 3 \mathrm{H}$ strain the characteristics were the earlier appearance of almost all behavioral components and the conspicuously delayed disappearance of hyperreactivity. The strain of DBA was distinctive in the earlier disappearance of rooting reflex, freezing and front placing reaction. There were no striking characteristics in BALB strain except the comparatively earlier appearance of hyperreactivity. In I20 strain the characteristics were found in the delayed appearance of walking 
and also in the delayed disappearance of all reflexes except hyperreactivity.

Kruskal-Wallis $H$ test was used to evaluate the age difference when a given behavioral components appeared or disappeared in five inbred strains. Significant strain differences were observed in all components examined $(p<0.001)$.

Therefore, individual comparisons between two inbred strains were administered by means of Mann-Whitney $U$ test. The results are shown in Table 1 . In many behavioral components, all compared pairs between five inbred strains showed the statistically significant differences in regard to the age in their appearance and disappearance with a few exceptions. Especially the differences be-
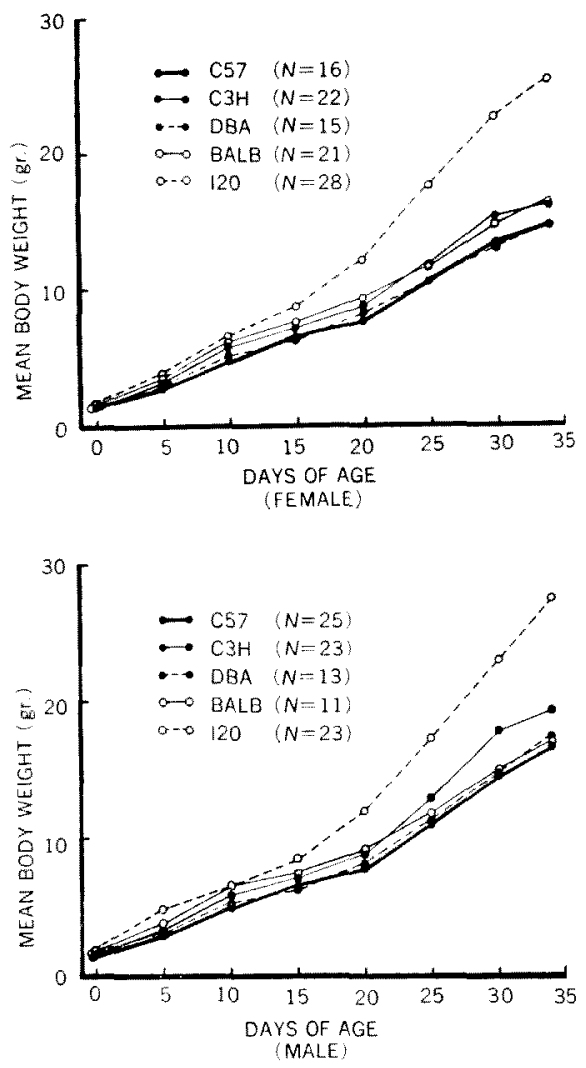

Fig. 2. Mean body weight in five inbred strains of mice. tween $\mathrm{C} 57$ and 120 mice, C57 and C3H mice, and $\mathrm{C} 3 \mathrm{H}$ and $\mathrm{I} 20$ mice were significant in almost behavioral components with a very few exceptions. These results indicate that there was the strain difference in the behavioral development of the young. This may suggest that the difference of genetic architecture in inbred strains is an important factor of behavioral devclopment.

The average litter size $( \pm S D)$ at birth was $5.9( \pm 1.0)$ in $\mathrm{C} 57,6.6( \pm 1.8)$ in $\mathrm{C} 3 \mathrm{H}, 4.7( \pm 1.4)$ in DBA, 6.4( \pm 1.0$)$ in BALB and $10.1( \pm 2.0)$ in 120 strain respectively. Figure 2 shows the average body weight in five inbred strains. Both female and male mice of 120 strain were significantly heavier than those of the other strains. C57 and DBA strains were the lightest in weight, the latter being so in spite of its smallest litter size.

\section{Experiment II}

In Experiment I, the difference of behavioral development was recognized in five inbred strains of mice. It was suggested that the genetic architecture of the inbred strain was an important factor of behavioral development. It is necessary, however, to consider the possibility that the strain differences of behavioral development result not only from the difference of genetic architecture but also from the different effects of maternal strain (pre- and postnatal maternal effects). Experiment II was then carried out to separate the postnatal maternal effect on behavioral development in inbred strains from the genetic architecture and the prenatal maternal effect by cross-fostering.

\section{Method}

Two inbred strains of mice, $\mathrm{C} 3 \mathrm{H}$ and I20, were used because they had distinct and different characteristics in behavioral development and stable fertility as shown in Experiment $\mathbf{I}$. Two groups of 39 pups each of $\mathrm{C} 3 \mathrm{H}$ and $\mathrm{I} 20$ fostered by 
Table 2

Median and range of the days of age and summary of Mann-Whitney $U$ test for behavioral components in four fostered groups

\begin{tabular}{|c|c|c|c|c|c|c|c|c|c|}
\hline & $\mathrm{C} / \mathrm{C}$ & $\mathrm{C} / \mathrm{I}$ & $1 / 1$ & $\mathrm{I} / \mathrm{C}$ & $\begin{array}{c}\mathrm{C} / \mathrm{C} \\
\mathrm{vs} . \\
\mathrm{I} / \mathbf{1}\end{array}$ & $\begin{array}{l}\mathrm{C} / \mathrm{C} \\
\mathrm{vs} . \\
\mathrm{C} / \mathrm{I}\end{array}$ & $\begin{array}{c}\mathrm{I} / \mathrm{I} \\
\mathrm{vs} . \\
\mathrm{I} / \mathrm{C}\end{array}$ & $\begin{array}{l}\mathrm{C} / \mathrm{C} \\
\mathrm{vs} . \\
\mathrm{I} / \mathrm{C}\end{array}$ & $\begin{array}{l}I / I \\
\text { vs. } \\
\mathrm{C} / \mathrm{I}\end{array}$ \\
\hline \multicolumn{10}{|l|}{ Appearance } \\
\hline Front placing & $\begin{array}{c}3.4 \\
(2-5)\end{array}$ & $\begin{array}{c}4.3 \\
(2-7)\end{array}$ & $\begin{array}{c}4.0 \\
(2-5)\end{array}$ & $\begin{array}{c}4.0 \\
(3-5)\end{array}$ & $* * *$ & $* *$ & - & $* *$ & - \\
\hline Back righting & $\begin{array}{c}3 \cdot 2 \\
(3-5)\end{array}$ & $\begin{array}{c}3.7 \\
(2-5)\end{array}$ & $\begin{array}{c}+.4 \\
(3-6)\end{array}$ & $\begin{array}{c}4.5 \\
(2-6)\end{array}$ & $* *$ & - & - & $* *$ & $* *$ \\
\hline Walking & $\begin{array}{c}9.3 \\
(7-11)\end{array}$ & $\begin{array}{c}9.3 \\
(7-12)\end{array}$ & $\begin{array}{l}11.4 \\
(9-15)\end{array}$ & $\begin{array}{l}11.3 \\
(6 \cdots 14)\end{array}$ & $* *$ & - & - & $* *$ & $* *$ \\
\hline Auditory startle & $\begin{array}{c}15.4 \\
(14-18)\end{array}$ & $\begin{array}{c}15.8 \\
(13-18)\end{array}$ & $\begin{array}{c}16.4 \\
(14-19)\end{array}$ & $\begin{array}{c}15.7 \\
(13-19)\end{array}$ & $* *$ & - & $* *$ & - & $* * *$ \\
\hline Hyperreactivity & $\begin{array}{c}9.1 \\
(8-11)\end{array}$ & $\begin{array}{c}9.7 \\
(8-11)\end{array}$ & $\begin{array}{c}11.9 \\
(10-14)\end{array}$ & $\begin{array}{l}10.8 \\
(9-14)\end{array}$ & $* *$ & $* *$ & $* *$ & $* * *$ & $* *$ \\
\hline Freezing & $\begin{array}{c}13.9 \\
(12-16)\end{array}$ & $\begin{array}{c}15.1 \\
(13-18)\end{array}$ & $\begin{array}{c}14.5 \\
(12-16)\end{array}$ & $\begin{array}{c}15.2 \\
(14-17)\end{array}$ & $*$ & $* *$ & $* *$ & $* * *$ & - \\
\hline \multicolumn{10}{|l|}{ Disappearance } \\
\hline Front placing & $\begin{array}{c}6.9 \\
(5-8)\end{array}$ & $\begin{array}{c}7.1 \\
(4-9)\end{array}$ & $\begin{array}{c}9.0 \\
(6-11)\end{array}$ & $\begin{array}{l}10.0 \\
(8-12)\end{array}$ & $* *$ & $\cdots$ & $* * *$ & ** & $* *$ \\
\hline Crossed extensor & $\begin{array}{c}3.7 \\
(3-5)\end{array}$ & $\begin{array}{c}5.2 \\
(4-8)\end{array}$ & $\begin{array}{c}5.8 \\
(4-7)\end{array}$ & $\begin{array}{c}6.7 \\
(6-9)\end{array}$ & $* *$ & $* *$ & $* *$ & $* *$ & * \\
\hline Rooting & $\begin{array}{c}12.7 \\
(10-15)\end{array}$ & $\begin{array}{c}12.6 \\
(10-14)\end{array}$ & $\begin{array}{l}14.9 \\
(13-17)\end{array}$ & $\begin{array}{l}15.5 \\
(12-18)\end{array}$ & $* *$ & - & $* *$ & $* *$ & $* *$ \\
\hline Auditory startle & $\begin{array}{c}20.4 \\
(18-25)\end{array}$ & $\begin{array}{c}20.9 \\
(17-27)\end{array}$ & $\begin{array}{l}25.7 \\
(22-33)\end{array}$ & $\begin{array}{c}25.8 \\
(21-33)\end{array}$ & $* *$ & - & - & $* *$ & ** \\
\hline Hyperreactivity & $\begin{array}{c}27.4 \\
(23-34)\end{array}$ & $\begin{array}{c}22.1 \\
(20-30)\end{array}$ & $\begin{array}{l}19.8 \\
(18-26)\end{array}$ & $\begin{array}{c}21.4 \\
(18-28)\end{array}$ & $* *$ & $* *$ & $* *$ & $* *$ & ** \\
\hline Freezing & $\begin{array}{c}22.8 \\
(16-32)\end{array}$ & $\begin{array}{c}26.0 \\
(16-34)\end{array}$ & $\begin{array}{c}32.6 \\
(22-34)\end{array}$ & $\begin{array}{c}33.8 \\
(24-34)\end{array}$ & $* *$ & $*$ & - & $* *$ & $* *$ \\
\hline
\end{tabular}

ten $\mathrm{C} 3 \mathrm{H}$ foster mothers $(\mathrm{C} / \mathrm{C}$ and $\mathrm{I} / \mathrm{C}$ respectively), and also two groups of the same number and strains as the above fostered by ten 120 foster mothers (C/I and $I / I$ respectively) were served as subjects. The litters were culled to seven or eight pups at birth and fostered from birth till weaning ( 20 days of age). The procedure of observation and the tests were the same as those in Experiment I. But pivoting was excluded from the observation because no significant difference was found between $\mathrm{C} 3 \mathrm{H}$ and $\mathrm{I} 20$ strains in Experiment $\mathrm{I}$.

Results

Table 2 shows the median and range of days of the age when a given behavioral component appeared or disappeared in four fostered groups. Kruskal-Wallis $H$ test was used to evaluate the differences of the age in the appearance and disappearance of behavioral components in four fostered groups. The age difference in the appearance of front placing reaction and auditory startle response was statistically significant at $p<0.01$ and that of the other behaviors at $p<0.001$. Therefore, individual comparisons between two fostered groups were administered by means of Mann-Whitney $U$ test (Table 2). Significant differences in the age between $\mathrm{C} / \mathrm{C}$ and $\mathrm{I} / \mathrm{I}$ (in-fostered groups) were found in all behavioral components with no exception. These results agree with those of Experiment I. 
Table 3

Median and range of the days of age and summary of Mann-Whitney $U$ test for behavioral components in inbred and hybrid mice

\begin{tabular}{|c|c|c|c|c|c|c|c|c|c|c|}
\hline & $\mathrm{C} 3 \mathrm{H}$ & 120 & CI & IC & $\begin{array}{c}\text { C3H } \\
\text { vs. } \\
120\end{array}$ & $\begin{array}{l}\mathrm{C} 3 \mathrm{H} \\
\mathrm{Vs} . \\
\mathrm{CI}\end{array}$ & $\begin{array}{c}\text { C3H } \\
\text { vs. } \\
\text { IC }\end{array}$ & $\begin{array}{l}\text { I } 20 \\
\text { vs. } \\
\text { CiI }\end{array}$ & $\begin{array}{l}120 \\
\text { vs. } \\
\text { IC }\end{array}$ & $\begin{array}{l}\text { CI } \\
\text { vs. } \\
\text { IC }\end{array}$ \\
\hline \multicolumn{11}{|l|}{ Appcarance } \\
\hline Front placing & $\begin{array}{c}2.7 \\
(1-4)\end{array}$ & $\begin{array}{c}3.2 \\
(3-4)\end{array}$ & $\begin{array}{c}3.7 \\
(3-5)\end{array}$ & $\begin{array}{c}2.5 \\
(1-3)\end{array}$ & $* *$ & $* *$ & - & $* *$ & $* *$ & ** \\
\hline Back righting & $\begin{array}{c}3.3 \\
(2-5)\end{array}$ & $\begin{array}{c}5.0 \\
(3-7)\end{array}$ & $\begin{array}{c}3.1 \\
(2-6)\end{array}$ & $\begin{array}{l}3.0 \\
(2-4)\end{array}$ & *** & $\circ$ & $\circ$ & $* *$ & $* *$ & - \\
\hline Walking & $\begin{array}{l}8.4 \\
(7-13)\end{array}$ & $\begin{array}{l}11.9 \\
(8-15)\end{array}$ & $\begin{array}{c}8.9 \\
(5-14)\end{array}$ & $\begin{array}{l}8.4 \\
(4-11)\end{array}$ & $* *$ & - & - & $* *$ & ** & - \\
\hline Auditory startle & $\begin{array}{c}14.9 \\
(13-16)\end{array}$ & $\begin{array}{c}15.7 \\
(13-18)\end{array}$ & $\begin{array}{c}14.0 \\
(13-16)\end{array}$ & $\begin{array}{c}14.8 \\
(13-16)\end{array}$ & $* *$ & $* *$ & - & $* *$ & $* *$ & $* *$ \\
\hline Hyperreactivity & $\begin{array}{c}8.7 \\
(8-10)\end{array}$ & $\begin{array}{l}10.9 \\
(9-12)\end{array}$ & $\begin{array}{c}8.8 \\
(7-12)\end{array}$ & $\begin{array}{c}9.5 \\
(9-12)\end{array}$ & $* *$ & - & $* *$ & $* *$ & $* *$ & $* *$ \\
\hline Freezing & $\begin{array}{c}14.5 \\
(13-16)\end{array}$ & $\begin{array}{c}15.7 \\
(14-18)\end{array}$ & $\begin{array}{c}13.9 \\
(12-16)\end{array}$ & $\begin{array}{c}13.6 \\
(12-15)\end{array}$ & $* *$ & $* *$ & $* *$ & $* *$ & $* *$ & ** \\
\hline \multicolumn{11}{|l|}{ Disappearance } \\
\hline Front placing & $\begin{array}{c}7.5 \\
(6-9)\end{array}$ & $\begin{array}{l}10.0 \\
(7-11)\end{array}$ & $\begin{array}{c}8.6 \\
(7-11)\end{array}$ & $\begin{array}{l}10.1 \\
(9-12)\end{array}$ & $* *$ & $* *$ & $* *$ & $* *$ & - & ** \\
\hline Crossed extensor & $\begin{array}{c}4.6 \\
(3-5)\end{array}$ & $\begin{array}{l}6.7 \\
(6-8)\end{array}$ & $\begin{array}{c}6.0 \\
(4-7)\end{array}$ & $\begin{array}{c}6.0 \\
(5-8)\end{array}$ & $* *$ & $* *$ & $* *$ & $* *$ & $* *$ & - \\
\hline Rooting & $\begin{array}{l}11.6 \\
(9-13)\end{array}$ & $\begin{array}{l}14.0 \\
(13-16)\end{array}$ & $\begin{array}{l}11.9 \\
(9-14)\end{array}$ & $\begin{array}{l}12.6 \\
(9-14)\end{array}$ & $* *$ & - & $* *$ & $* *$ & $* *$ & $\circ$ \\
\hline Auditory startle & $\begin{array}{c}21.1 \\
(18-26)\end{array}$ & $\begin{array}{c}26.1 \\
(19-31)\end{array}$ & $\begin{array}{c}25.6 \\
(20-31)\end{array}$ & $\begin{array}{c}25.4 \\
(19-31)\end{array}$ & $* *$ & $* *$ & ** & - & - & - \\
\hline Hyperreactivity & $\begin{array}{c}28.8 \\
(26-34)\end{array}$ & $\begin{array}{c}21.0 \\
(19-23)\end{array}$ & $\begin{array}{c}29.3 \\
(22-34)\end{array}$ & $\begin{array}{c}24.9 \\
(22-30)\end{array}$ & $* *$ & - & $* *$ & ** & $* *$ & ** \\
\hline Freezing & $\begin{array}{c}22.2 \\
(17-30)\end{array}$ & $\begin{array}{c}28.3 \\
(17-34)\end{array}$ & $\begin{array}{l}25.0 \\
(16-29)\end{array}$ & $\begin{array}{c}18.9 \\
(16-24)\end{array}$ & $* * *$ & $* *$ & $* *$ & $* *$ & $* *$ & ** \\
\hline
\end{tabular}

Postnatal maternal effects was detected by comparing $\mathrm{C} / \mathrm{C}$ with $\mathrm{C} / \mathrm{I}$, and $\mathrm{I} / \mathrm{I}$ with I/C (out-fostered groups). Significant differences were found in both in the appearance of hyperreactivity and freezing and in the disappearance of crossed extensor reflex and hyperreactivity. No significant difference was, however, found in both in the appearance of back righting reflex and walking and in the disappearance of auditory startle response.

Pups outfostered (C/I and I/C) resembled the alien strain in the appearance and the disappearance of hyperreactivity, but not other components.

If the behavioral development is strongly determined by the genetic architecture or affected by the prenatal maternal en- vironment, it is expected that there are significant differences between $\mathrm{C} / \mathrm{C}$ and $I / C$ and between $I / I$ and $C / I$ strains. Significant differences were found in almost all the behavioral components. An attempt to separate the prenatal maternal effect from the genetic architecture was carried out in Experiment IV.

\section{Experiment III}

In Experiment II was found the postnatal maternal effect on the behavioral development in inbred mice. The purpose of Experiment III was to examine the mode of inheritance in behavioral components and the reciprocal maternal effect (including both prenatal and postnatal effect) 
by the reciprocal crossing.

\section{Method}

The subjects were 39 C3H pups, 39 I20 pups, and their reciprocal hybrids (39 CI and 39 IC pups). CI is hybrid between $\mathrm{C} 3 \mathrm{H}$ mother and $\mathrm{I} 20$ father, and $\mathrm{IC}$ is between $\mathrm{I} 20$ mother and $\mathrm{C} 3 \mathrm{H}$ father. $\mathrm{C} 3 \mathrm{H}$ and 120 were chosen because of their characteristic behavioral development and their breeding facility as detected in Experiment II. Behavioral components, procedure, and litter size were the same as those in Experiment II.

\section{Results}

Table 3 shows the medians and ranges of the age when given behavioral components appeared or disappeared in $\mathrm{C} 3 \mathrm{H}$, I20, CI, and IC pups. Kruskal-Wallis $H$ test was used to evaluate the difference of the age in the four groups. The age of the disappearance of auditory startle response was significant at $p<0.05$ and that
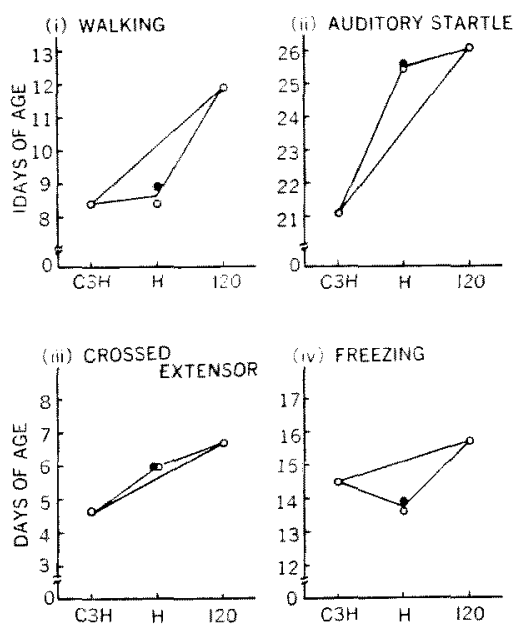

Fig. 3. The mode of inheritance. i) and ii) are complete dominance, iii) partial dominance, and iv) overdominance. i) is the appearance of walking, ii) the disappearance of auditory startle response, iii) the disappearance of crossed extensor reflex, and iv) the appearance of freezing. $\mathrm{H}$ means hybrids. Open circle is IC and solid circle CI. Median age is shown in ordinate. of the other behavioral components at $p<0.001$. Therefore, individual comparisons between two groups were administered by means of Mann-Whitney $U$ test. Significant differences in the age between $\mathrm{C} 3 \mathrm{H}$ and $\mathrm{I} 20$ were also found in all the behavioral components examined in this experiment with no exception (Table 3 ).

Behavioral characteristics of hybrid mice were grouped into three types $(\mathrm{a}, \mathrm{b}$, and c). They were categorized according to the degree of developmental resemblance of hybrids to either parental strains. The hybrid score was the median age of CI and IC. Typical examples were shown in Fig. 3. In Type (a) hybrids resemble in behavioral development to either one of their parental strains, which revealed in the appearance of back righting reflex and walking, and the disappearance of auditory startle response and freezing (Fig. 3-i, Fig. 3-ii). In type (b) the resemblance was intermediate in the age between the two parental strains, which revealed in the appearance of front placing reaction, hyperreactivity, and the disappearance of crossed extensor reflex, front placing reaction, rooting reflex, and hyperreactivity (Fig. 3-iii). In Type (c), both hybrids lie outside the range of their two parental strains, which appeared in the appearance of freezing and auditory startle response: this phenomenon is called hybrid vigor (Fig. 3-iv). It may be suggested that three types of the mode of inheritance in behavioral components (a, b, and c) correspond to complete dominance, partial dominance, and overdominance respectively.

The reciprocal maternal effect was detected by comparing CI with IC. Significant difference was found in seven behavioral components as shown in Table 3 : the appearance of front placing reaction, auditory startle response, hyperreactivity and freezing, and the disappearance of front placing reaction, hyperreactivity and freezing. These results indicate that 
Table 4

Median and range of the days of age and summary of Mann-Whitney $U$ test for behavioral components in four fostered hybrid groups

\begin{tabular}{|c|c|c|c|c|c|c|c|c|}
\hline & $\mathrm{CI} / \mathrm{C}$ & $\mathrm{CI} / \mathrm{I}$ & $\mathrm{IC} / \mathrm{C}$ & $\mathrm{IC} / \mathrm{I}$ & $\begin{array}{l}\mathrm{CI} / \mathrm{C} \\
\mathrm{vs} . \\
\mathrm{IC} / \mathrm{C}\end{array}$ & $\begin{array}{l}\mathrm{CI} / \mathrm{I} \\
\text { Vs. } \\
\mathrm{IC} / \mathrm{I}\end{array}$ & $\begin{array}{l}\mathrm{GI} / \mathrm{C} \\
\text { vs. } \\
\mathrm{CI} / \mathrm{I}\end{array}$ & $\begin{array}{l}\mathrm{IC} / \mathrm{C} \\
\mathrm{vs} \\
\mathrm{IC} / \mathrm{I}\end{array}$ \\
\hline \multicolumn{9}{|l|}{ Appearance } \\
\hline Front placing & $\begin{array}{c}3.6 \\
(1-5)\end{array}$ & $\begin{array}{c}4.3 \\
(3-6)\end{array}$ & $\begin{array}{c}3.8 \\
(1-5)\end{array}$ & $\begin{array}{c}2.2 \\
(1-4)\end{array}$ & $一$ & $* *$ & $* *$ & $* *$ \\
\hline Auditory startle & $\begin{array}{c}14.2 \\
(13-16)\end{array}$ & $\begin{array}{c}14.9 \\
(13-17)\end{array}$ & $\begin{array}{c}14.6 \\
(13-16)\end{array}$ & $\begin{array}{c}14.8 \\
(12-17)\end{array}$ & - & - & $* *$ & - \\
\hline Hyperreactivity & $\begin{array}{c}9.3 \\
(9 \cdots 11)\end{array}$ & $\begin{array}{l}10.5 \\
(8-12)\end{array}$ & $\begin{array}{c}9.2 \\
(8-11)\end{array}$ & $\begin{array}{c}9.2 \\
(8-12)\end{array}$ & - & $* *$ & $* *$ & - \\
\hline Freezing & $\begin{array}{c}13.0 \\
(12-15)\end{array}$ & $\begin{array}{c}14.4 \\
(12-17)\end{array}$ & $\begin{array}{c}13.5 \\
(12-15)\end{array}$ & $\begin{array}{c}13.0 \\
(10-15)\end{array}$ & 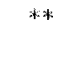 & $* *$ & $* *$ & $*$ \\
\hline \multicolumn{9}{|l|}{ Disappearance } \\
\hline Front placing & $\begin{array}{c}7.0 \\
(6-8)\end{array}$ & $\begin{array}{l}9.4 \\
(7-11)\end{array}$ & $\begin{array}{l}8.8 \\
(7-11)\end{array}$ & $\begin{array}{c}9.1 \\
(8-11)\end{array}$ & $* *$ & - & $* *$ & $\circ$ \\
\hline Hyperreactivity & $\begin{array}{c}28.8 \\
(22-33)\end{array}$ & $\begin{array}{c}23.9 \\
(20-33)\end{array}$ & $\begin{array}{c}28.7 \\
(20-34)\end{array}$ & $\begin{array}{c}27.4 \\
(22-32)\end{array}$ & - & ** & $* *$ & - \\
\hline Freezing & $\begin{array}{c}26.0 \\
(20-34)\end{array}$ & $\begin{array}{c}24.3 \\
(19-34)\end{array}$ & $\begin{array}{c}26.4 \\
(19-34)\end{array}$ & $\begin{array}{c}29.7 \\
(23-34)\end{array}$ & - & ** & - & - \\
\hline
\end{tabular}

prenatal and/or postnatal maternal effects were important in seven behavioral components in hybrid mice.

\section{Experiment IV}

In Experiment III the maternal effect revealed on the behavioral development in hybrid mice from the prenatal period to the age of 34 days. Experiment IV was then carried out to separate the prenatal maternal effect from the postnatal by reciprocal crossing and cross-fostering.

\section{Method}

The subjects were $78 \mathrm{CI}$ pups fostered by five $\mathrm{C} 3 \mathrm{H}$ mothers and five $\mathrm{I} 20$ mothers (39 CI/C and $39 \mathrm{CI} / \mathrm{I}$ pups respectively), and $78 \mathrm{IC}$ pups fostered by five $\mathrm{C} 3 \mathrm{H}$ mothers and five $\mathrm{I} 20$ mothers $(39 \mathrm{IC} / \mathrm{C}$ and $39 \mathrm{IC} / \mathrm{I}$ pups respectively). The procedure was the same as in Experiment II. Seven behavioral components in which the reciprocal maternal effect was recognized in Experiment III were measured: the appearance of front placing reaction, auditory startle response, hyperreactivity and freezing and the disappearance of front placing reaction, hyperreactivity and freezing.

Results

Table 4 shows the medians and ranges of the age when given behavioral components appeared or disappeared in the four fostered groups. Kruskal-Wallis $H$ test was used to evaluate the differences of the age in the appearance and disappearance of behavioral components in the four groups. The appearance of auditory startle response was statistically significant at $p<0.05$, the appearance of front placing reaction and the disappearance of hyperreactivity at $p<0.01$, and the other components at $p<0.001$. Therefore, individual comparisons between two groups were administered by means of Mann-Whitney $U$ test (Table 4).

Prenatal maternal effect was detected by comparing $\mathrm{CI} / \mathrm{C}$ with $\mathrm{IC} / \mathrm{C}$, and $\mathrm{CI} / \mathrm{I}$ with IC/I, because the genetic architecture of the pairs and the strains of the foster 
mothers of each pair were the same but the strains of prenatal mothers in each pair were different. The appearance of freezing and the disappearance of front placing reaction were statistically significant between CI/C and IC/C. Between $\mathrm{CI} / \mathrm{I}$ and $\mathrm{IC} / \mathrm{I}$, significant differences were found in the appearance of front placing reaction, hyperreactivity and freezing. Consequently, the prenatal maternal effect on the appearance of freezing was common in both pairs, but not of the other components.

Postnatal maternal effect was detected by comparing $\mathrm{CI} / \mathrm{C}$ with $\mathrm{CI} / \mathrm{I}$, and $\mathrm{IC} / \mathrm{C}$ with $\mathrm{IC} / \mathrm{I}$, because the genetic architecture of the pairs and the strains of prenatal mothers in each pair were both the same but the strains of foster mothers in each pair were different. There were significant differences in all the measurements but the disappearance of freezing between $\mathrm{CI} \mathrm{C}$ and $\mathrm{CI} / \mathrm{I}$.

Between IC/C and IC/I, significant differences were found in the appearance of front placing reaction and that of freezing. Consequently the postnatal maternal effect on the appearance of front placing reaction and freezing was common in both pairs, but not in regard of the other behavioral components.

\section{Discussion}

Many reflexes and body movements in young rodents have been examined by several investigators (Fox, 1965; Scudder et al., 1967; McClearn et al., 1970). Fox (1965) reported five developmental stages in mice: perinatal, neonatal, postnatal transitional, postnatal infantile and juvenile stages. They were essentially similar to those in this study.

In Experiment $I$, the heaviest strain was $\mathrm{I} 20$, the next $\mathrm{C} 3 \mathrm{H}$, and the lightest was C57. But the behavioral development order was $\mathrm{C} 3 \mathrm{H}, \mathrm{C} 57$ and $\mathrm{I} 20$ strains in its appearance, and $\mathrm{C} 57, \mathrm{C} 3 \mathrm{H}$ and $\mathrm{I} 20$ strains in its disappearance. Mikuni and
Nash (1979) carried out a comparative study between the Goodale Giant inbred strain and a random bred strain. They pointed out that rapid growth and increased size were not directly correlated with behavioral maturation. This agrees with the results of Experiment I where no close relation was found between body weight and behavioral development.

The major purpose of this study was to examine the strain difference and the mode of inheritance of the behavioral development and the maternal effect on it. Scudder et al. (1967) studied the development and behavior of the young of several genera and strains of mice until the age of 20 days. McClearn et al. (1970) investigated the behavior of the pups of two inbred strains of mice and heterogeneous stocks from birth to the age of 15 days. Wahlsten (1975) assessed the developmental status of six inbred strains and three $F_{2}$ hybrids crosses of mice at 32 days after conception. They reported that there were strain differences in behavioral development of mice. It was confirmed in Experiment $I$. The strains of $\mathrm{C} 57, \mathrm{C} 3 \mathrm{H}$ and $\mathrm{I} 20$ were obviously different from one another in many behavioral components examined. The strain of DBA resembled $\mathrm{C} 57$ or BALB in some components. The strain of BALB had intermediate values among the strains examined. These results suggest that the difference of genetic architecture among inbred strains is the important source of the difference of the behavioral development.

In order to investigate the mode of inheritance, hybrid pups were produced by reciprocal crossing between $\mathrm{C} 3 \mathrm{H}$ and $\mathrm{I} 20$ strain, which were extremely different from each other in many behavioral components. Judging from Table 3, the relation between hybrids and parental strains was classified into three types. Typical examples were shown graphically in Fig. 3. It may be suggested that the three types of the mode of inheritance in 
behavioral components are complete dominance, partial dominance, and overdominance (hybrid vigor) respectively.

McClearn et al. (1970), Wahlsten (1975), and Wainwright (1980) recognized hybrid vigor in many behavioral components of the young mice. In Experiment III, however, only two components (the appearance of freezing and that of auditory startle response) showed hybrid vigor. Therefore, hybrid vigor would not always be found in the behavioral components of the young.

As for the relative contribution of the postnatal maternal environment to strain differences, cross-fostering would be a useful technique for its detection and analysis. In Experiment II, postnatal maternal effect in inbred mice was recognized in several behavioral components, especially in the appearance of hyperreactivity and freezing and in the disappearance of crossed extensor reflex and hyperreactivity. Pups outfostered resembled the alien strain in the development of hyperreactivity, but not in the other components. It indicates that the direction of the postnatal maternal effect on the development of behavioral components of the young is not always toward that of his postnatal maternal strain.

van Abeelen (1980) found that C57BL pups outfostered were better buffered against maternal influences than DBA/2 pups outfostered. In Experiment II, some behavioral components in $\mathrm{C} 3 \mathrm{H}$ mice affected by the alien foster mother were not the same as those in 120 mice. As van Abeelen pointed out, one possible consideration of these results would be that there are strain differences in sensitivity to the maternal environment,

The four components, where there was no postnatal maternal effect, are the appearance of back righting reflex and walking, and the disappearance of auditory startle response and freezing. They seemed to be genetically determined or affected by prenatal maternal environ- ment.

It is, however, important to detect the contribution of prenatal maternal effect to the genetic architecture. For this purpose, reciprocal hybrids which have the same genetic architecture were used. The comparison between them may enable us to detect the pre- and postnatal maternal effect. Moreover, the separation of the prenatal maternal effect from the postnatal is possible by cross-fostering between reciprocal hybrids. In Experiment IV, the appearance of freezing was affected by the prenatal maternal environment. The components influenced by the postnatal maternal environment were the appearance of front placing reaction and freezing and the disappearance of front placing reaction.

It is interesting that the appearance of freezing is affected both by prenatal and postnatal maternal environments. Freezing is considered as an emotional response. Thompson (1957) found that prenatal maternal stress has some effects on the emotionality of the young. His findings were confirmed by several investigators (Ader \& Belfer, 1962; Morra, 1965). Broadhurst (1961) carried out selection in the open field test and obtained two divergent lines: emotionally reactive and non reactive line. He investigated the prenatal and postnatal maternal effects by cross-fostering and reciprocal crossing between divergent lines. He found, however, that there was little evidence in favor of the operation of maternal influences on emotional characteristics. The results obtained in Experiment IV agree with the findings of Thompson.

\section{References}

Ader, R., \& Belfer, M. 1962 Prenatal maternal anxiety and offspring emotionality in the rat. Psychological Reports, 10, 711-718.

Barnett, S. S., \& Burn, J. 1967 Early stimulation and maternal behavior. Nature, 213, 150152. 
Broadhurst, P. L. 1961 Analysis of maternal effects in the inheritance of behaviour. Animal Behaviour, 9, 129-1+1.

Fox, M.W. 1965 Reflex-ontogeny and behavioural development of the mouse. Animal $B e$ haviour, 13, 234-241.

McClearn, G. E., Wilson, J. R., \& Meredith, W. 1970 The use of isogenic and heterogenic mouse stocks in behavioral research. In $G$. Lindzey \& D. D. Thiessen (Eds.), Contributions to behavior-genetic analysis: The mouse as a prolotype. New York: Appleton-Century-Crofts. Pp. 3-22.

Mikuni, P. A., \& Nash, D.J. 1979 Ontogeny of behavior in mice selected for large size. Behavior Gentitis, 9, 227-232.

Morra, M. 1965 Prenatal sound stimulation on postnatal rat offspring open field behaviors. Psychological Record, 15, 571-575.

Scudder, C. L., Karczmar, A. G., \& Lockett, L. 1967 Behavioural developmental studies on four genera and several strains of mice. Animal Behaviour, 15, 353-363.

Slob, A. K., Snow, C. E., \& de Natris-Mathot, E.
1973 Absence of behavioural deficits following neonatal undernutrition in the rat. Developmental Psychobiology, 6, 177-186.

Thompson, W. R. 1957 Influence of prenatal anxiety on emotionality in young rats. Scicnce, 125, 698-699.

Wainwright, P. 1980 Relative eflects of maternal and pup heredity on postnatal mouse development. Developmental Psychobiology, 13, 493-498.

van Abcelen, J.H.F. 1963 Mouse mutants studied by means of ethological methods. I. Ethogram. Genetica, 34, 79-94.

van Abeelen, J.H.F. 1980 Direct genetic and maternal infuences on behavior and growth in two inbred mouse strains. Behavior Genetics, 10, 545-551.

Wahlsten, D. 1975 Genetic variation in the development of mouse brain and behavior: Evidence from the middle postnatal period. Developmental Psychobiology, 8, 371-380.

(Received Oct. 5, 1981; accepted March 13, 1982) 